\title{
PENERAPAN MODEL PEMBELAJARAN EKSPLICIT INTRUCTION UNTUK MENINGKATKAN HASIL BELAJAR IPA FISIKA PADA SISWA KELAS VIII SMP NEGERI 1 LORE TENGAH
}

\section{Ikhnan Hojin ${ }^{1}$, I Wayan Darmadi ${ }^{2}$ dan Nurjannah ${ }^{3}$}

Email: ikhnan_hojin@yahoo.co.id

Program Studi Pendidikan Fisika, Jurusan Pendidikan MIPA, Universitas Tadulako

Jl. Soekarno Hatta, KM.9, Kampus Bumi Tadulako Tondo Palu - Sulawesi Tengah

\begin{abstract}
Abstrak - Penelitian ini bertujuan untuk meningkatkan hasil belajar IPA fisika siswa. Masalah yang diteliti adalah rendahnya hasil belajar siswa pada mata pelajaran IPA Fisika. Alternatif pemecahan masalah adalah

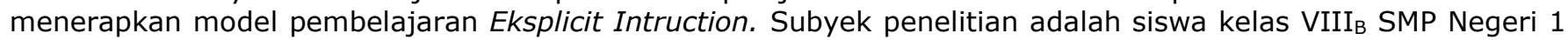
Lore Tengah, dengan jumlah siswa 26 orang. Penelitian ini menggunakan penelitian tindakan kelas yang dilaksanakan dalam dua siklus dengan materi pokok Tekanan, masing-masing siklus meliputi 4 tahap: (i) perencanaan (ii) pelaksanaan tindakan (iii) observasi (iv) refleksi. Penerapan model pembelajaran Eksplicit

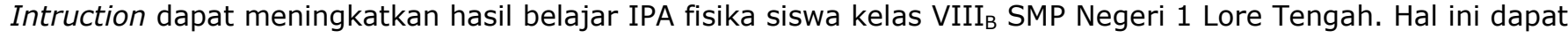
dilihat pada peningkatan hasil belajar siswa dari siklus I ke siklus II. Untuk hasil belajar siklus I diperoleh nilai ketuntasan belajar klasikal sebesar $76,91 \%$ dan daya serap klasikal sebesar $67,69 \%$. Sedangkan pada siklus II diperoleh nilai ketuntasan belajar klasikal sebesar $92,31 \%$ dan daya serap klasikal sebesar $82,70 \%$ yang artinya sudah melebihi standar ketuntasan belajar siswa. Peningkatan ketuntasan belajar klasikal dan daya serap klasikal dari siklus I ke siklus II sebesar 20,02\% dan $22,17 \%$ untuk hasil observasi aktifitas siswa dan guru pada siklus I yaitu cukup dan baik, sedangkan pada siklus II observasi aktivitas siswa dan guru berada pada kategori baik dan sangat baik.
\end{abstract}

Kata Kunci: Model Pembeajaran Eksplicit Intruction, Hasil Belajar IPA Fisika; Tekanan

\section{PENDAHULUAN}

Pendidikan merupakan salah satu aspek yang berperan dalam mengembangkan mutu sumber daya manusia suatu bangsa. Peningkatan mutu tersebut dapat dilakukan dengan mengembangkan metode, model dan strategi belajar mengajar dalam pendidikan. Mata pelajaran fisika merupakan salah satu mata pelajaran yang dalam proses pembelajarannya terhadap pengetahuan, cara berfikir dan penyelidikannya membutuhkan metode, model dan strategi pembelajaran yang tepat. Penerapan metode, model dan strategi pembel ajaran diharapkan dapat meningkatkan hasil belajar sesuai dengan tujuan pembelajaran yang diharapkan.

Berdasarkan hasil observasi di SMP Negeri 1 Lore Tengah, guru IPA fisika kelas VIII menyatakan bahwa nilai kriteria ketuntasan minimal untuk mata pelajaran IPA Fisika yaitu 65, didapatkan data rata-rata hasil belajar fisika siswa kelas VIII selama dua semester terakhir masih rendah yaitu 60. Guru IPA fisika kelas VIII menyatakan bahwa model pembelajaran yang diterapkan pada saat mengajar yaitu menggunakan metode caramah dan metode tanya jawab. Menurut guru kelas VIII, metode diskusi kelompok sangat jarang digunakan karena siswanya sulit diatur dan siswanya cenderung saling mengganggu jika menggunakan metode tersebut. Hal ini menjadi alasan oleh guru untuk lebih memilih menggunakan metode pembelajaran konvensional. Dalam pembelajaran konvensional guru juga jarang memberikan soal-soal latihan kepada siswa. 


\section{Jurnal Pendidikan Fisika Tadulako (JPFT) \\ Vol. 1 No. 2}

ISSN 23383240

Selanjutnya, berdasarkan hasil wawancara dengan siswa-siswa kelas VIII, mereka menyatakan bahwa pembelajaran fisika merupakan pembelajaran yang sukar dan sulit. Hal ini karena didalam pembelajaran fisika banyak tertdapat teori-teori, hukum-hukum dan rumus-rumus yang sulit untuk mereka pahami, serta cara mengajar guru fisika yang cenderung membosankan. Banyak diantara siswa mengatakan bahwa mengikuti pelajaran fisika hanya untuk sekedar mengisi daftar hadir saja agar dapat memperoleh nilai, sehingga berimplikasi pada hasil belajar yang rendah. Hal ini dapat dilihat dari hasil belajar siswa kelas VIII SMP Negeri 1 Lore Tengah tahun 2012/2013 pada Tabel 1.

Tabel 1. Hasil Belajar IPA Fisika Siswa Kelas VIII Tahun 2012/2013

\begin{tabular}{|c|c|c|}
\hline NO & Kelas & Nilai Rata-rata \\
\hline 1. & VIII $^{\mathrm{A}}$ & 60,30 \\
2. & $\mathrm{VIII}^{\mathrm{B}}$ & 56,50 \\
3. & $\mathrm{VIII}^{\mathrm{C}}$ & 58,90 \\
\hline
\end{tabular}

(Sumber: Data SMP Negeri 1 Lore Tengah)

Berdasarkan Tabel 1 terlihat bahwa hasil belajar fisika belum maksimal. Salah satu upaya untuk meningkatkan hasil belajar siswa yaitu menerapkan suatu model pembelajaran yang membuat seluruh siswa aktif dan dapat memahami pembelajaran dalam proses belajar mengajar. Oleh karena itu, diterapkan model Explicit Intruction sebagai model pembelajaran yang digunakan dalam tindakan perbaikan untuk meningkatkan hasil belajar IPA fisika pada siswa kelas VIIIB SMP Negeri 1 Lore Tengah. Model Pembelajaran Explicit Intruction merupakan model pembelajaran yang dapat menciptakan suasana siswa dalam kelas menjadi lebih menyenangkan sehingga siswa tidak merasa tegang dalam proses pembelajaran. Dengan model pembelajaran tersebut, pengajar dapat menciptakan suasana belajar dimana siswa bekerja secara gotong royong dan saling berinteraksi satu sama lain.

Berdasarkan penelitian sebelumnya, model pembelajaran ini pernah diterapkan oleh Sri Yuningsi dan diperoleh kesimpulan bahwa terdapat perbedaan hasil belajar fisika antara siswa yang mengikuti model pembelajaran Eksplicit Intructian dengan pembelajaran konvensional pada siswa kelas X SMK Negeri 1 Binjai, yang mana hasil belajar fisika siswa yang mengikuti pembelajaran Explicit Instruction lebih meningkat dibandingkan siswa yang mengikuti pembelajaran konvensional (Sri Yuningsi, 2011).

Hipotesis tindakan pada penelitian ini adalah penerapan model pembelajaran Eksplicit Intruction dapat meningkatkan hasil belajar fisika pada siswa kelas VIII B SMP Negeri 1 Lore Tengah.

\section{METODOLOGI PENELITIAN}

Penelitian ini merupakan penelitian tindakan kelas (PTK) yang dilakukan dalam dua siklus. Masing-masing siklus melalui tahap perencanaan, pelaksanaan, observasi dan refleksi. Tahapan penelitian ni diadopsi dari alur PTK model Kurt Lewin yang dikembangkan oleh Mc. Taggart (Depdiknas, 2004).

Subyek penelitian ini adalah seluruh siswa kelas VIII B SMP Nageri 1 Lore Tengah yang terdaftar pada semester ganjil tahun ajaran 2012/2013 yang berjumlah 26 orang siswa yang terdiri dari 10 orang siswa laki-laki dan 16 orang siswa perempuan, metode pengumpulan data pada penelitian ini, meliputi beberapa cara yaitu, observasi menggunakan lembar observasi dan tes hasil belajar. Faktor-faktor 
yang diteliti dalam penelitian ini adalah aktivitas guru, aktivitas siswa, afektif siswa, psikomotor siswa, dan kinerja kelompok siswa, serta hasil belajar siswa. Analisa data terbagi menjadi dua kelompok yaitu analisa data kuantitatif dan data kualitatif.

\section{HASIL DAN PEMBAHASAN}

Data hasil analisis observasi aktivitas guru siklus I dan siklus II dapat dilihat pada Tabel 3.1 berikut:

Tabel 2 Hasil Analisis Observasi Aktivitas Guru Siklus I dan siklus II

\begin{tabular}{|c|c|c|c|}
\hline Siklus & Pertemuan & $\begin{array}{c}\text { Persentase } \\
\text { yang } \\
\text { diperoleh }\end{array}$ & Kategori \\
\hline \multirow{2}{*}{ Satu } & Pertama & $79,27 \%$ & Cukup \\
\cline { 2 - 4 } & Kedua & $88,64 \%$ & Baik \\
\hline \multirow{2}{*}{ Dua } & Pertama & $95,45 \%$ & $\begin{array}{c}\text { Sangat } \\
\text { Baik }\end{array}$ \\
\hline
\end{tabular}

Berdasarkan Tabel 2 dapat dilihat bahwa persentase nilai rata-rata aktivitas guru siklus I pada pertemuan pertama berada pada kategori cukup, sedangkan pada pertemuan kedua berada pada kategori baik. Pada siklus II persentase nilai rata-rata aktivitas guru berada pada kategori sangat baik.

Data hasil analisis observasi aktivitas siswa siklus I dan siklus II dapat dilihat pada Tabel 3 berikut:

Tabel 3 Hasil Analisis Observasi Aktivitas Siswa Siklus I dan siklus II

\begin{tabular}{|c|c|c|c|}
\hline Siklus & Pertemuan & $\begin{array}{c}\text { Persentase } \\
\text { yang diperoleh }\end{array}$ & Kategori \\
\hline \multirow{2}{*}{ Satu } & Pertama & $77,50 \%$ & Cukup \\
\cline { 2 - 4 } & Kedua & $84,00 \%$ & Baik \\
\hline Dua & Pertama & $92,00 \%$ & $\begin{array}{c}\text { Sangat } \\
\text { Baik }\end{array}$ \\
\hline
\end{tabular}

Berdasarkan Tabel 3, dapat dilihat bahwa persentase nilai rata-rata aktivitas siswa siklus I pada pertemuan pertama berada pada kategori cukup, sedangkan pada pertemuan kedua berada pada kategori baik. Pada siklus II persentase nilai rata-rata aktivitas siswa berada pada kategori sangat baik.

Data hasil analisis observasi penilaian afektif siswa siklus I dan siklus II dapat dilihat pada Tabel 4 berikut:

Tabel 4 Hasil Analisis Penilaian Afektif Siswa Siklu I dan siklus II

\begin{tabular}{|c|c|c|c|}
\hline Siklus & Pertemuan & $\begin{array}{c}\text { Persentase } \\
\text { keberhasilan }\end{array}$ & Kategori \\
\hline \multirow{2}{*}{ Satu } & Pertama & $78,13 \%$ & Cukup \\
\cline { 2 - 4 } & Kedua & $84,15 \%$ & Baik \\
\hline \multirow{2}{*}{ Dua } & Pertama & $91,15 \%$ & $\begin{array}{c}\text { Sangat } \\
\text { Baik }\end{array}$ \\
\hline
\end{tabular}

Berdasarkan Tabel 4, dapat dilihat bahwa persentase nilai rata-rata keberhasilan afektif siswa siklus I pada pertemuan pertama berada pada kategori cukup, sedangkan pada pertemuan kedua berada pada kategori baik. Pada siklus II persentase nilai rata-rata aktivitas siswa berada pada kategori sangat baik.

Data hasil analisis observasi penilaian kinerja kelompok siswa siklus I dan siklus II dapat dilihat pada Tabel 5 berikut:

Tabel 5 Hasil Analisis Penilaian Kinerja Kelompok Siswa Siklus I

\begin{tabular}{|c|c|c|c|}
\hline Siklus & Pertemuan & $\begin{array}{c}\text { Persentase } \\
\text { keberhasilan }\end{array}$ & Kategori \\
\hline \multirow{2}{*}{ Satu } & Pertama & $71,63 \%$ & Cukup \\
\cline { 2 - 4 } & Kedua & $85,56 \%$ & Baik \\
\hline \multirow{2}{*}{ Dua } & Pertama & $92,55 \%$ & $\begin{array}{c}\text { Sangat } \\
\text { Baik }\end{array}$ \\
\hline
\end{tabular}




\section{Jurnal Pendidikan Fisika Tadulako (JPFT) \\ Vol. 1 No. 2}

ISSN 23383240

Berdasarkan Tabel 5, dapat dilihat bahwa persentase nilai rata-rata keberhasilan kinerja kelompok siswa siklus I pada pertemuan pertama berada pada kategori cukup, dan pada pertemuan kedua berada pada kategori baik Pada siklus II persentase nilai rata-rata keberhasilan kinerja kelompok siswa berada pada kategori sangat baik.

Data hasil analisis observasi penilaian psikomotor siswa siklus I dan siklus II dapat dilihat pada Tabel 6 berikut:

Tabel 6 Hasil Analisis Penilaian Psikomotor Siswa Siklus I dan siklus II

\begin{tabular}{|c|c|c|c|}
\hline Siklus & Pertemuan & $\begin{array}{c}\text { Persentase } \\
\text { keberhasilan }\end{array}$ & Kategori \\
\hline \multirow{2}{*}{ Satu } & Pertama & $73,56 \%$ & Cukup \\
\cline { 2 - 4 } & Kedua & $86,54 \%$ & Baik \\
\hline \multirow{2}{*}{ Dua } & Pertama & $91,11 \%$ & $\begin{array}{c}\text { Sangat } \\
\text { Baik }\end{array}$ \\
\hline
\end{tabular}

Berdasarkan Tabel 6, dapat dilihat bahwa persentase nilai rata-rata keberhasilan penilaian psikomotor siswa siklus I pada pertemuan pertama berada pada kategori cukup, sedangkan pada pertemuan kedua berada pada kategori baik. Pada siklus II persentase nilai rata-rata penilaian psikomotor siswa berada pada kategori sangat baik.

Data hasil analisis observasi penilaian psikomotor kelompok siswa siklus I dan siklus II dapat dilihat pada Tabel 7 berikut:

Tabel 7 Hasil Analisis Penilaian Psikomotor Kelompok Siklus I

\begin{tabular}{|c|c|c|c|}
\hline Siklus & Pertemuan & $\begin{array}{c}\text { Persentase } \\
\text { keberhasilan }\end{array}$ & Kategori \\
\hline \multirow{2}{*}{ Satu } & Pertama & $71,63 \%$ & Cukup \\
\cline { 2 - 4 } & Kedua & $88,56 \%$ & Baik \\
\hline \multirow{2}{*}{ Dua } & Pertama & $93,75 \%$ & $\begin{array}{c}\text { Sangat } \\
\text { Baik }\end{array}$ \\
\hline
\end{tabular}

Berdasarkan Tabel 7, dapat dilihat bahwa persentase nilai rata-rata keberhasilan penilaian psikomotor kelompok siklus I pada pertemuan pertama berada pada kategori cukup, dan pada pertemuan kedua berada pada kategori baik Pada siklus II persentase nilai rata-rata keberhasilan psikomotor kelompok berada pada kategori sangat baik.

Data hasil belajar siswa siklus I dan siklus II secara lengkap ditunjukkan oleh Tabel 8 berikut:

Tabel 8 Hasil Belajar Siswa Siklus I dan Siklis II

\begin{tabular}{|c|l|c|c|}
\hline \multirow{2}{*}{ No. } & \multirow{2}{*}{ Aspek Perolehan } & \multicolumn{2}{|c|}{ Hasil } \\
\cline { 3 - 4 } & & Siklus I & $\begin{array}{c}\text { Siklus } \\
\text { II }\end{array}$ \\
\hline 1. & Skor maksimal & 100 & 100 \\
\hline 2 & Skor tertinggi & 90 & 95 \\
\hline 3 & $\begin{array}{l}\text { Banyaknya siswa } \\
\text { yang memperoleh } \\
\text { skor tertinggi }\end{array}$ & 1 orang & $\begin{array}{c}3 \\
\text { orang }\end{array}$ \\
\hline 4 & Skor terendah & 45 & 60 \\
\hline 5 & $\begin{array}{l}\text { Banyaknya siswa } \\
\text { yang memperoleh } \\
\text { skor terendah }\end{array}$ & 1 orang & $\begin{array}{c}2 \\
\text { orang }\end{array}$ \\
\hline 6 & $\begin{array}{l}\text { Banyaknya siswa } \\
\text { yang tuntas }\end{array}$ & $\begin{array}{c}20 \\
\text { orang }\end{array}$ & $\begin{array}{c}24 \\
\text { orang }\end{array}$ \\
\hline 7 & $\begin{array}{l}\text { Banyaknya siswa } \\
\text { yang tidak tuntas }\end{array}$ & 6 orang & $\begin{array}{c}2 \\
\text { orang }\end{array}$ \\
\hline 8 & $\begin{array}{l}\text { Persentase daya } \\
\text { serap klasikal }\end{array}$ & $69,98 \%$ & $\begin{array}{c}82,70 \\
\%\end{array}$ \\
\hline 9 & $\begin{array}{l}\text { Persentase } \\
\text { ketuntasan belajar } \\
\text { klasikal }\end{array}$ & $76,91 \%$ & $\begin{array}{c}92,31 \\
\%\end{array}$ \\
\hline
\end{tabular}

Berdasarkan analisa tes hasil belajar yang dilakukan pada siklus I, diketahui bahwa hasil belajar fisika siswa kelas VIII B SMP Negeri 1 Lore Tengah sudah cukup baik, hanya ada 6 siswa yang tidak tuntas dari 26 siswa sedangkan ketuntasan belajar klasikal (KBK) siswa mencapai $76,91 \%$ dan daya serap klasikal (DSK) siswa mencapai 69,98 \%, akan tetapi hasil ini belum memenuhi indicator 


\section{Jurnal Pendidikan Fisika Tadulako (JPFT) \\ Vol. 1 No. 2}

standar ketuntasan belajar klasikal dan daya serap klasikal yang harus mencapai $80 \%$.

Adapun penyebab masih belum tercapainya standar ketuntasan klasikal dan standar ketuntasan daya serap klasikal pada siklus I disebabkan oleh beberapa faktor yaitu terlalu cepat dalam menyampaikan materi pembelajaran, sehingga kurang dimengerti dan dipahami oleh siswa. Sebagian besar siswa juga masih banyak yang kurang aktif dalam KBM dan masih malu-malu atau ragu-ragu dalam menyampaikan pendapatnya maupun bertanyaz, hal ini dikarenakan siswa hanya terbiasa dengan metode ceramah yang diberikan oleh guru, yang menyebabkan siswa terbiasa dengan menunggu sajian dari guru saja. Dalam mengerjakan tugas kelompok siswa juga belum bisa membangun kebersamaan, komunikasi dan kerja sama yang baik dalam kelompok masing-masing, ini dikarenakan siswa belum terbiasa dengan metode diskusi kelompok. Hal ini dapat dilihat dari hasil analisis aktivitas guru dan aktivitas siswa yang di gambarkan seperti gambar 1 .

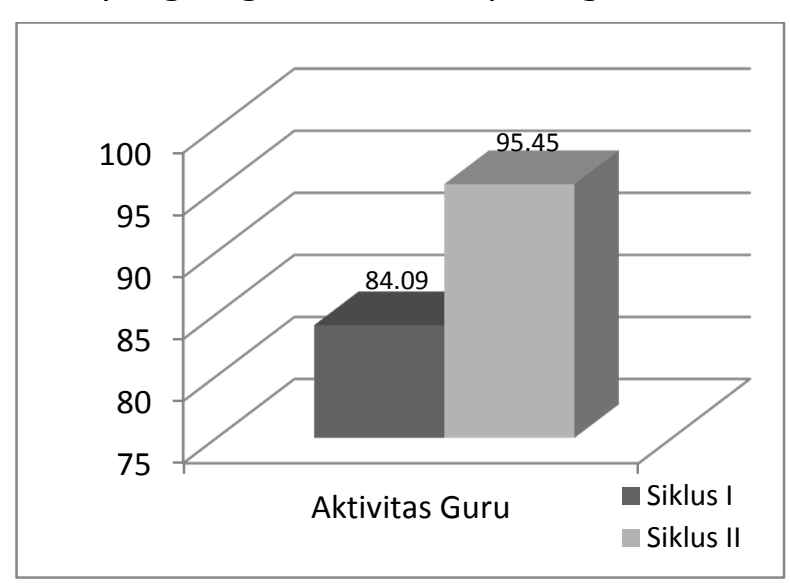

ISSN 23383240

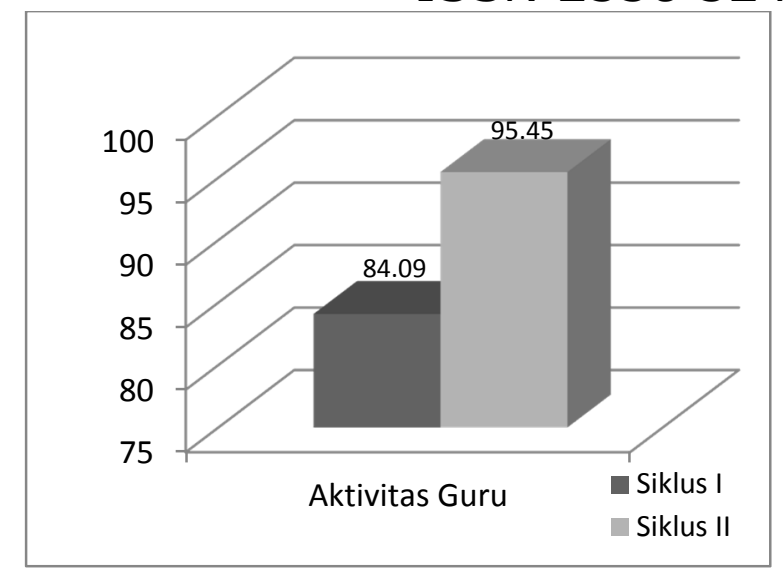

Gambar 1 grafik aktivitas guru dan aktivitas

siswa siklus I ke siklus II

Berdasarkan gambar grafik 1, dapat dikatakan bahwa aktivitas guru dan siswa selama mengikuti proses pembelajaran siklus I dan siklus II sudah mengalami peningkatan. Guru berusaha memperhatikan dan memperbaiki kekurangan-kekurangan yang dilakukan pada pertemuan-pertemuan sebelumnya (siklus I), sehingga pada pertemuan ketiga (siklus II) guru dapat meminimalisir kekurangan-kekurangan tersebut. Hal inilah yang menyebabkan terjadinya peningkatan pada aktivitas guru dan aktivitas siswa.

Pada setiap tahap pembelajaran peran guru sangat berpengaruh terhadap peningkatan aktivitas siswa. Guru berusaha mempehatikan masalah-masalah yang dihadapi oleh siswa pada saat melaksanakan pembelajaran dan berusaha mendorong siswa agar mampu mengungkapkan ide-ide mereka dan membangun konsepnya melalui pembelajaran. Guru juga berusaha mendorong siswa agar lebih aktif dalam melakukan kegiatan pembelajaran karena dari pelaksanaan kegiatan ini mereka diharapkan lebih aktif dalam mencari dan memahami materi yang diajarkan. 
Berdasarkan hasil analisis data kualitatif tes hasil belajar siswa pada siklus I dan siklus II terlihat adanya peningkatan hasil belajar siswa. Hal ini terlihat dari hasil belajar yang diperoleh siswa yaitu pada siklus I diperoleh presentase ketuntasn klasikl sebesar 76,91\% dan presentase daya serap klasikal diperoleh sebesar $67,69 \%$ dimana masih ada 6 orang siswa yang belum tuntas dari 26 orang siswa. Sedangkan pada siklus II presentase ketuntasan klasikal diperoleh sebesar 92,31\% dan presentase daya serap klasikal sebesar $82,70 \%$. Dimana siswa yang belum tuntas berkurang menjadi 2 orang siswa dari 26 orang siswa. Dari data tersebut dapat dilihat bahwa terjadi peningkatan ketuntasan klasikal sebesar $20,02 \%$ dan daya serap klasikal sebesar $22,17 \%$. Hal ini dapat dilihat dari grafik ketuntasan klasikal dan daya serap klasikal siklus I dan siklus II pada gambar 2 berikut.

Gambar 2 Grafik Peningkatan Hasil Belajar IPA Fisika Siswa Siklus I dan Siklus II

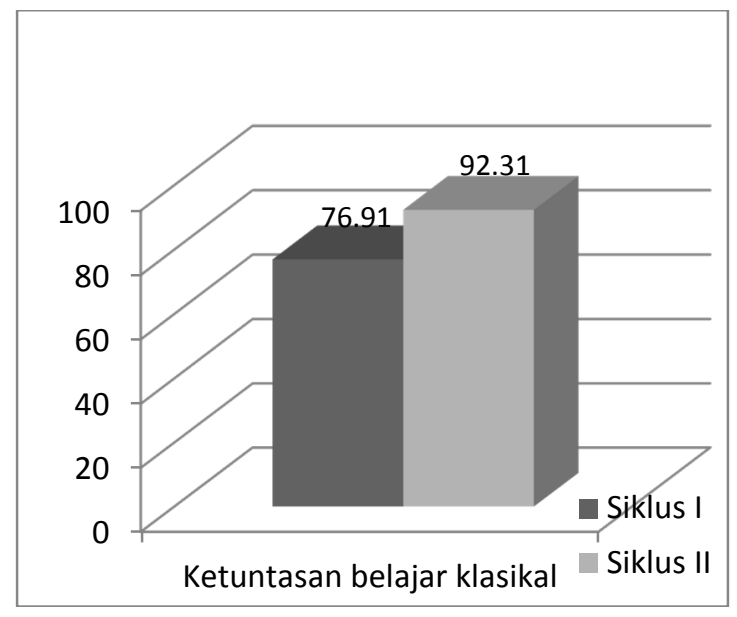

ISSN 23383240

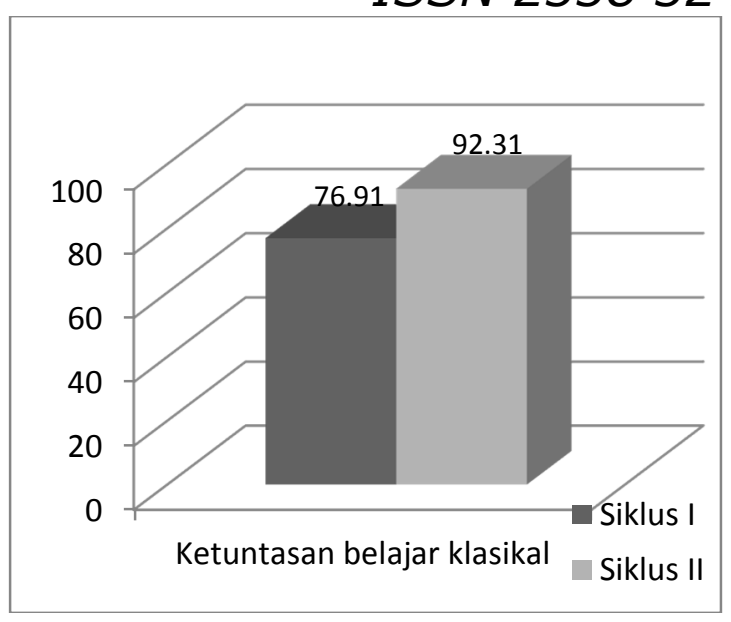

Gambar 2 Grafik ketuntasan klasikal dan daya serap klasikal siklus I dan siklus II

Upaya yang dilakukan untuk meningkatkan ketuntasan klasikal dan daya serap klasikal, yaitu guru berusaha memperjelas lagi dalam menyampaikan materi pembelajaran, memotivasi siswa agar lebih aktif dalam mengikuti KBM dan lebih banyak lagi memberikan contoh-contoh soal. Guru juga lebih membangun keakraban dengan siswa sehingga siswa tidak merasa malu-malu dan ragu-ragu lagi dalam bertanya dan mengungkapkan masalah-masalah yang mereka hadapi.

Dengan adanya refleksi tindakan dimana peneliti mencari kekurangan dari pembelajaran siklus I, dan merekomendasikan kekurangan untuk diperbaiki pada pembelajaran siklus II. Pada hasil belajar siswa pada siklus II diketahui bahwa hasil yang diperoleh sudah memenuhi indikator keberhasilan kuantitatif dengan ketuntasan klasikal sebesar 92,31\% yang berada pada kategori sangat baik dengan peningkatan dari siklus I sebesar 20,02\%, dan daya serap klasikal sebesar $82,70 \%$ yang berada ada kategori baik dengan peningkatan dari siklus I sebesar 22,17\%. Dari data tersebut 


\section{Jurnal Pendidikan Fisika Tadulako (JPFT)}

Vol. 1 No. 2

ISSN 23383240

dapat dilihat bahwa hasil yang diperoleh pada siklus II dapat meningkat lebih baik dari siklus I karena faktor-faktor penyebab kegagalan pada siklus I dapat diminimalisir.

Berdasarkan uraian di atas, dapat dikatakan bahwa penerapan model pembelajaran explicit intruction dapat meningkatkan hasil belajar IPA fisika siswa kelas VIII SMP Negeri 1 Lore Tengah. Hal ini disebabkan karena penggunaan model pembelajaran explicit intruction menekankan pada keaktifan siswa dalam pembelajaran, dengan adanya demonstrasi yang dilakukan oleh guru membuat siswa merasa senang dan memiliki keinginan untuk melakukan kegiatan tersebut. Setelah melakukan demonstrasi guru berperan sebagai fasilitator yang dapat membimbing dan mengarahkan siswa untuk lebih aktif, sehingga dalam proses pembelajaran menjadikan siswa terlibat langsung dengan kegiatan yang dialami dan dilakukannya sendiri dengan membuat hipotesis atas permasalahan tersebut, karena konsep suatu materi dalam pembelajaran fisika tidak hanya untuk diketahui, tetapi bagaimana proses pembentukannya untuk diketahui dan dipahami.

\section{KESIMPULAN}

Berdasarkan hasil analisis data penelitian tindakan kelas ini dapat disimpulkan bahwa penerapan model pembelajaran Eksplicit Intruction dapat meningkatkan hasil belajar IPA fisika pada siswa kelas VIII B SMP Negri 1 Lore Tengah. Hal ini ditunjukkan pada hasil siklus I diperoleh ketuntasan belajar klasikal sebesar $76,91 \%$ serta daya serap klasikal sebesar $67,69 \%$. Meningkat pada siklus II dengan ketuntasan belajar klasikal sebesar 92,31\% serta daya serap klasikal sebesar $82,70 \%$. Peningkatan ketuntasan belajar klasikal (KBK) dan daya serap klasikal (DSK) dari siklus I ke siklus II sebesar 20,02 \% dan 22,17\%. Dan hasil observasi aktivitas iswa dan guru pada siklus I berada pada kategori cukup dan baik, dan mengalami peningkatan pada siklus II yaitu berada pada kategori sangat baik.

\section{Daftar Pustaka}

[1] Depdiknas. 2004. Penelitian Tindakan Kelas. Jakarta: Direktorat Pendidikan Nasional

[2] Uno dan Nurdin, 2011. Model Pembelajaran Explicit Intruction,

http://jurnalbidandiah.blogspot.com/2012/04/model pembelajaran-explicit intruction.html\#ixzz2HVAUmDSY. Diakses tanggal 15 Maret 2012.

[3] Yuningsi, Sri. 2011. Perbedaan Hasil Belajar Fisika Antara Penerapan Model Pembelajaran Eksplicit Intruction Dengan Pembelajaran Konvensional Pada Siswa Kelas X SMK Negeri 1 Binjai. http://www.hariyono.org/2011/10/model-pembelajaranexplicit-intruction.html. diakses tanggal 15 maret 2012. 